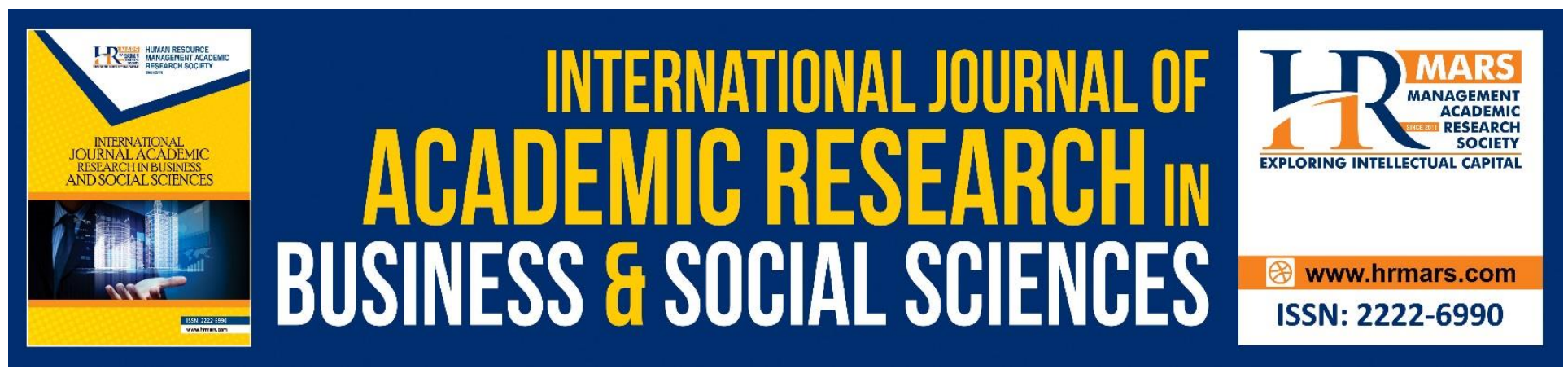

\title{
Ramification of Crowdfunding on Entrepreneur Self-efficacy
}

Abu Shams Mohammad Mahmudul Hoque, Zainudin Awang, Habsah Muda Fauzilah Salleh, Norfadzilah Rashid, Asyraf Afthanorhan

To Link this Article: http://dx.doi.org/10.6007/IJARBSS/v8-i12/5081 DOI: $10.6007 /$ IJARBSS/v8-i12/5081

Received: 23 Nov 2018, Revised: 17 Dec 2018, Accepted: 26 Dec 2018

Published Online: 30 Dec 2018

In-Text Citation: (Hoque, Awang, Salleh, Rashid, \& Afthanorhan, 2018)

To Cite this Article: Hoque, A. S. M. M., Awang, Z., Salleh, H. M. F., Rashid, N., \& Afthanorhan, A. (2018). Ramification of Crowdfunding on Entrepreneur Self-efficacy. International Journal of Academic Research in Business and Social Sciences, 8(12), 882-895.

Copyright: (C) 2018 The Author(s)

Published by Human Resource Management Academic Research Society (www.hrmars.com)

This article is published under the Creative Commons Attribution (CC BY 4.0) license. Anyone may reproduce, distribute, translate and create derivative works of this article (for both commercial and non-commercial purposes), subject to full attribution to the original publication and authors. The full terms of this license may be seen at: http://creativecommons.org/licences/by/4.0/legalcode

Vol. 8, No. 12, 2018, Pg. 882 - 895

Full Terms \& Conditions of access and use can be found at http://hrmars.com/index.php/pages/detail/publication-ethics 


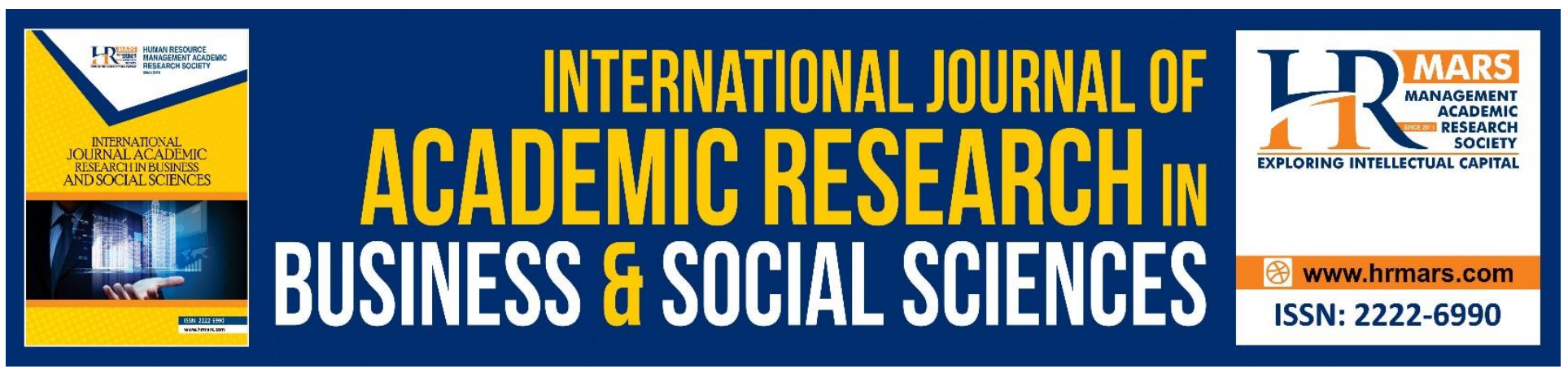

\section{Ramification of Crowdfunding on Entrepreneur Self- efficacy}

\section{${ }^{1}$ Abu Shams Mohammad Mahmudul Hoque *2Zainudin Awang ${ }^{3}$ Habsah Muda ${ }^{4}$ Fauzilah Salleh, ${ }^{5}$ Norfadzilah Rashid, ${ }^{6}$ Asyraf Afthanorhan}

1,2,3,4,5,6 Faculty of Economics and Management Sciences, Universiti Sultan Zainal Abidin

Terengganu, Malaysia

*220rresponding Author Email: zainudinawang@unisza.edu.my

\section{Abstract}

The innovative funding sources become more and more important in the SME sector all over the world especially after the 2007-2008 world financial crisis. In order to develop a new business idea, start-ups and SMEs need a sufficient amount of capital. However, after the financial crisis in 2008, SME sector faced the challenges of attracting new capital. Due to that, an innovative method of fundraising for SME is introduced as crowdfunding. Crowdfunding indicates financing a project or an idea via the internet owing the help from the many investors or donors of a society. Though computer based supportive work studies have initiated to explore how this new type of system influences entrepreneurial work, less is known about the influence of Crowdfunding on Entrepreneur Selfefficacy (ESE) to succeed at a business task. Hence, to minimize the research gap and to achieve the objective of the study, we conducted a quantitative research of 190 entrepreneurs using crowdfunding based on Social Cognitive theory. Based on gender, male entrepreneur constituted $57 \%$ while female entrepreneur represented $43 \%$ of the sample population. The data were analyzed using Structural Equation Modeling (SEM) in IBM-SPSS-Amos 25.0 and the stated hypotheses were tested. The study found the following direct effects are positive and significant namely, Crowdfunding on Entrepreneur's Self-efficacy $(\beta=0.924, P=.001)$. Overall, the result has landed support for crowdfunding can influence self-efficacy of entrepreneur. In order to prove the need of crowdfunding, we have explained and statistically proved that how crowdfunding can provide an additional channel through which firms can obtain finance and take an advantage of fully exploiting the potential of the internet as well as to create self-efficacy of entrepreneurs.

Keywords: Crowdfunding, Entrepreneur Self-efficacy, Structural Equation Modeling (SEM). 


\section{Introduction}

Bolton (1971), and Macmillan (1931), stated that in the last century the financing of entrepreneurial ventures has been a debated extensively by the academic scholars and by policy-makers. Over-all, it seems that small and medium enterprises (SMEs) have recurrent problems in obtaining the financial resources that are lifeblood for growth. Since the beginning of the 20th century, all over the world the governments in nations have tried different approaches in promoting the quality and quantity of financing that is available to small entrepreneurial ventures. Hence, the innovative funding sources become more and more important in the SME sector specially after 2007-2008 world financial crisis. In order to develop a new business idea, start-ups and SME needs a sufficient amount of capital. However, after the financial crisis in 2008, SME sector faced the challenges of attracting new capital. Due to that, an innovative method of fundraising for SME is introduced as crowdfunding. Silver, Berggren, and Fili (2016); Belleflamme et al., (2014); Ward and Ramachandran (2010) mentioned that, crowdfunding is financial activities for supporting projects with or without maximizing profit using Internet. According to Silver, Berggren, and Fili (2016), crowdfunding can partly be attributed to the emerging microfinance community and in some cases still is correlated to this type of funding. Ordanini et al. (2011) revealed that crowdfunding has been specifically valuable for financing inimitable projects that usually find it hard to get funding from more conventional sources of finance. Even political projects have been crowdfunded, for instance a majority of Barrack Obama's election campaign funds in 2008 came from small financial contributions (Silver et al., 2016; Eranti, 2014). So, crowdfunding indicates financing a project or an idea via the internet owing the help from the many investors or donors of a society. Though computer based supportive work studies have initiated to explore how this new type of system influences entrepreneurial work, less is known about the influence of crowdfunding on entrepreneur self-efficacy to succeed at a business task, which affects by searching, planning, marshaling, and implementing.

\section{Literature Review}

Money is raised either directly or through online platforms using Web 2.0 technologies from the people living in different geographical areas is known as crowdfunding which is also a new funding practice (Bottiglia and Pichler, 2016). Even though crowdfunding may appear to be a new trend, but in fact, it is not as in 1876, the Statue of Liberty was funded via crowdfunding, with the citizens of France for the statue and the United States for the pedestal (Bottiglia and Pichler, 2016; Best and Neiss 2014). However, the current epidemic growth of crowdfunding is mostly due the 2007-2008 global financial crisis as well as to the technological innovation of Web 2.0. It is widely recognized that bank credit has almost ceased after the collapse of the US bank Lehman Brothers mostly in Europe and North America and serious financial crisis broke out in the year 2007-2008 (Bottiglia and Pichler, 2016). Hence, financing for SMEs and individuals lessened dramatically and significantly during the crisis, which generating a gap for crowdfunding as an unconventional system for raising money (Hagedorn and Pinkwart, 2016; Bottiglia and Pichler, 2016; Dapp, 2013). As a result, distinct types of crowdfunding alternatives has been developed over time. 


\section{Crowdfunding}

Crowdfunding is a new internet-based method of fundraising in which individuals solicit contributions for projects on specialized crowdfunding websites (Bottiglia and Pichler, 2016). It is clear from the definition that three features are essential in crowdfunding: (1) there must be a business project that requires funding; (2) there must be many investors (or backers) that wish to contribute to the realization of that business-investors should be mainly, or in some cases exclusively, nonprofessional; and (3) the internet connects backers and entrepreneurs (Bottiglia and Pichler, 2016).

Based on the works of Moritz and Block, (2016); Hagedorn and Pinkwart, (2016); Wardrop et al., (2015); Belleflamme et al., (2014); Dix and Luzar, (2014); Wilson and Testoni, (2014); Pierrakis and Collins, (2013); Harrison, (2013); De Buysere et al. (2012); and Hemer (2011) the dimensions of crowdfunding is given below:

Donations: people give their money to a project or an idea and do not expect anything in exchange for the money. This is the typical dimension of crowdfunding used by not-for-profit and charitable organizations, including disaster-relief campaigns and election campaigns (Harrison, 2013; Pierrakis and Collins, 2013).

Sponsoring: in sponsoring the initiator and the investor agree on some kind of reward which enhances the credibility and social standing of the investor.

Pre-selling: in this case the compensation is the material award of buying a unique product before those not participating or even at the exclusion of those not participating (Wardrop et al., 2015; Belleflamme et al., 2014).

Social Lending: Through social lending, the money is collected using online platforms for social projects only and not pay interest or principal (De Buysere et al. 2012).

Equity: in this case the donors are provided with a certain number of shares in a profit-driven venture. This dimension is one of the more complicated transactions in the crowdfunding area (Moritz and Block 2016; Hagedorn and Pinkwart, 2016; Dix and Luzar 2014; Wilson and Testoni 2014).

Therefore, crowdfunding denotes to conditions in which many people provide, naturally small amounts of money to projects and ideas either directly or via online platforms.

\section{Self-efficacy}

The changeable nature of entrepreneurial work, distinct the design of a new venture (Shane,2003), requires that entrepreneurs confidence in their own capabilities appropriately to take action (McMullen, and Shepherd, 2006). According to Chen, Greene, and Crick (1998) entrepreneurial selfefficacy is entrepreneur's own capabilities to succeed at entrepreneurial tasks, influences performance positively as well as to set the goals of entrepreneur (Chen et. al., 1998). Self-efficacy can significantly influence entrepreneurial intentions and performance. On the other hand, 
INTERNATIONAL JOURNAL OF ACADEMIC RESEARCH IN BUSINESS AND SOCIAL SCIENCES Vol. 8, No. 12, Dec, 2018, E-ISSN: 2222-6990 @ 2018 HRMARS

crowdfunding can significantly influence the entrepreneur's self-efficacy. Rauch and Frese (2007), also mentioned that entrepreneurial self-efficacy for starting a new business is a crucial factor in increasing the likelihood of business start-up activity. Consequently, lack of fund or limited financing negatively affect the self-efficacy of an entrepreneur as well as lacks of self-efficacy is unlikely to pursue new ventures and believe in their own abilities (Chen et al., 1998). Bandura's Social Cognitive Theory suggests that self-efficacy can be developed in four ways: experience of mastery i.e. seeing oneself succeed at tasks, modeling i.e. seeing examples of similar others succeeding at tasks, social persuasion i.e. getting feedback and encouragement from others, and physiological states i.e. physical and emotional response to various situations (Bandura, 1997). While we understand how self-efficacy develops in face-to-face contexts, we know little about how entrepreneurial self-efficacy develops in a computer-mediated experience, specifically through crowdfunding. Hence, the purpose of this research is to explore the effect of crowdfunding on the self-efficacy of an entrepreneur as well as knowing that we can generate healthier socio-technical interfaces to support entrepreneurs as they engage in their work. Hence the hypothesis of this study is:

H 1: Crowdfunding has a positive and significant effect on Self-efficacy of an entrepreneur.

\section{Conceptual Framework of the Study}

This study has been formulated based on Bandura's Social Cognitive Theory and the variables under investigation in this study are shown in the following schematic diagram.

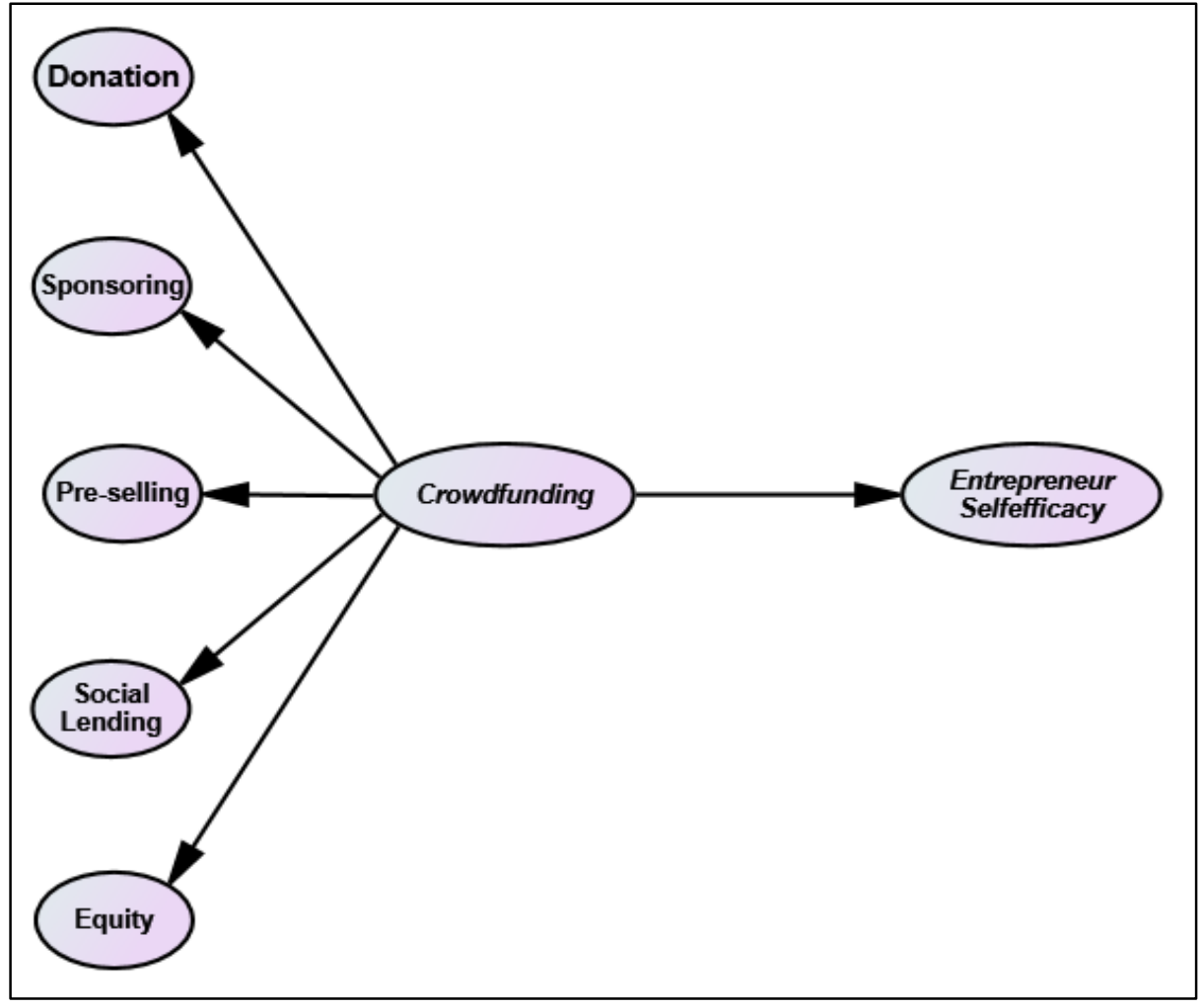

Figure 1: The Research Framework 


\section{Research Methodology \\ Sample and Data Collection}

The purpose of this research is to investigate the effect of crowdfunding on Entrepreneur Self Efficacy. The perceptions of owners of SMEs in Bangladesh were obtained through self-administered survey questionnaire to analyze the effect. In this regard, the survey questionnaire were distributed to the randomly selected respondents. The respondents were selected from the sampling frame which consists of the owners of SMEs in Bangladesh. A total of 190 usable samples was obtained. Grounded on gender, male constituted $57 \%$ while female represented $43 \%$ of the sampled respondents.

\section{Instrumentation}

The ESE measuring items was adapted from the work of Wilson et al., (2007) and the items were customized to suit the current study. The items of Crowdfunding was adapted from the work of Wingerden and Ryan (2011), and also customized to suit the study at hand. All items are using the subjective measure with Seven-point interval scale (with $1=$ strongly disagree and $7=$ strongly agree). These instruments has gone through the pre-testing stages namely, expert verification for content validity, measurement validity and face validity prior to collecting data for pilot study. The pilot study data has undergone the Exploratory Factor Analysis (EFA) procedure using Principal Component Analysis or PCA procedure for extraction method.

The EFA steps has verified the factor loading for items, the total variance explained for both constructs and the Cronbach's Alpha which reflect the internal reliability of items measuring the respective construct. The factor loading for all items exceed 0.6 , the total variance explained is 0.76 for CF and 0.81 ESE. Lastly, the Cronbach Alpha for CF and ESE were 0.81 and 0.87 respectively. Once the pilot study stages were completed and all measures were acceptable, the study began the field study data collection. The data from field study were subjected to Confirmatory Factor Analysis (CFA) procedure to validate all constructs prior to modelling the structural model and performing the Structural Equation Modeling (SEM).

\section{Method of Analysis}

SEM is the Second Generation method of multivariate analysis technique developed to cater limitations in the traditional Ordinary Least Squares (OLS) and the analysis for latent constructs is no longer appropriate with traditional OLS (Hoque et al., 2017a; Hoque et al., 2017b; Afthanorhan et al., 2017; Hoque and Awang, 2016a; Kashif et al., 2016; Awang, 2015; Awang et al., 2015a, Mohamad et al., 2016; Yusof et al., 2017). Thus the researchers employed SEM so as to keep pace with the advancement in research methodology. Not only that, using IBM-SPSS-AMOS software, the researchers could convert their theoretical framework directly into the Amos Graphics for analysis. In SEM, the researcher validated the measurement model of a latent construct using the Confirmatory Factor Analysis (CFA) procedure. Once validated, the researcher assembled the constructs into the structural model and execute the Structural Equation Modeling (SEM) procedure. Consequently, this study employed IBM-SEM-AMOS software package for analysis and testing the hypothesis. 
INTERNATIONAL JOURNAL OF ACADEMIC RESEARCH IN BUSINESS AND SOCIAL SCIENCES

Vol. 8, No. 12, Dec, 2018, E-ISSN: 2222-6990 C 2018 HRMARS

\section{Results}

\section{Measurement Model of the Construct}

Prior to modeling the structural model and executing SEM, the study needs to validate the measurement model of latent constructs for unidimensionality, validity, and reliability (Hoque et al., 2017a; Hoque et al., 2017b; Afthanorhan et al., 2017; Hoque and Awang, 2016a; Awang et al. 2015a, Mohamad et al., 2016; Yusof et al., 2017). Unidimensionality is achieved when the factor loading for all items are positive with a minimum value of 0.6 (Hoque et al., 2017a; Hoque et al., 2017b; Hoque and Awang, 2016a; Awang et al. 2015; Hair et al., 2014; Awang, 2015).

The Construct Validity is achieved when the fitness indexes for the measurement model meet three model fit categories namely, Absolute Fit, Incremental Fit, and Parsimonious Fit. The Discriminant Validity is achieved when all constructs are not highly correlated (Awang, 2015; Awang et al. 2015; Hair et al., 2014; Fornell and Larcker, 1981). The Convergent Validity is achieved when the value of Average Variance Extracted (AVE) meet the minimum value of 0.5 (Mohamad et al., 2016; Yusof et al., 2017; Hair et al., 2014).

The Construct Reliability is achieved when the values of Composite Reliability (CR) and Average Variance Extracted (AVE) reach the minimum value of 0.6 and 0.5 respectively (Awang et al., 2017a; Hoque et al., 2017a, Hoque et al., 2017b; Hoque and Awang, 2016a; Awang et al. 2015; Awang 2015; Hair et al., 2014; Fornell and Larcker, 1981). The Construct Validity is achieved when the fitness indexes have achieved certain level. As shown in Figure 2, all the Fitness Indexes (P-Value=.000; RMSEA=.073; $I F I=.939 ; \mathrm{CFI}=.938 ; \mathrm{TLI}=.928 ; \mathrm{NFI}=.903 ; \mathrm{ChiSq} / \mathrm{df}=2.546$ ) have achieved the required level. Hence, this study achieved the construct validity (Hoque and Awang, 2016a; Awang et al., 2017a; Awang 2015; Awang et al. 2015; Mohamad et al., 2016; Yusof et al., 2017 ). 


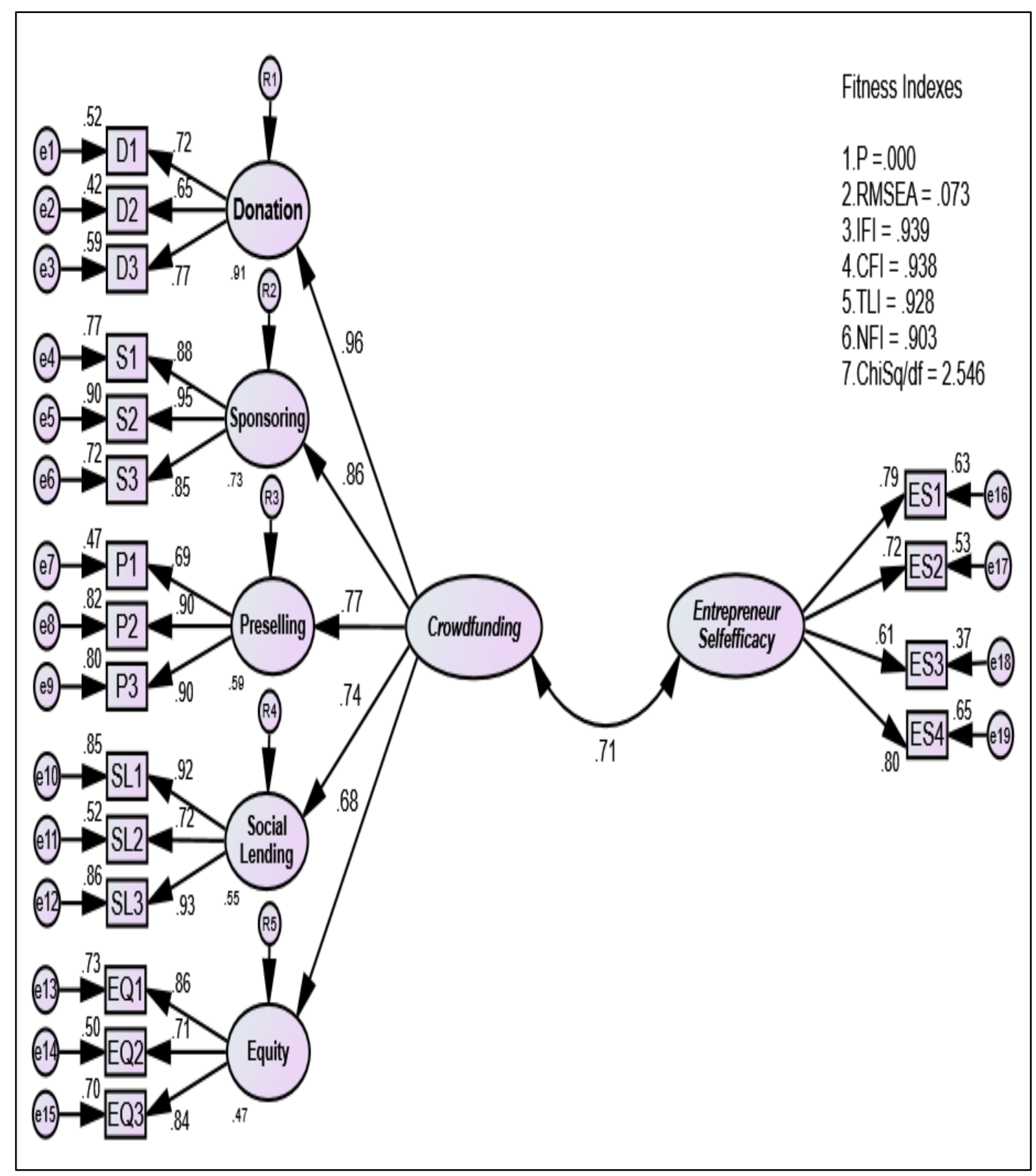

Figure 2: The Pooled CFA Results and the Output Showed All Fitness Indexes Achieved

The computation for values of Average Variance Extracted (AVE) which reflect the convergent validity and Composite Reliability (CR) which reflect the reliability of the constructs (crowdfunding and entrepreneur self-efficacy) are made in Table 1. 
INTERNATIONAL JOURNAL OF ACADEMIC RESEARCH IN BUSINESS AND SOCIAL SCIENCES Vol. 8, No. 12, Dec, 2018, E-ISSN: 2222-6990 C 2018 HRMARS

Table 1: Items Description, Internal Reliability, Composite Reliability and Convergent Validity

\begin{tabular}{|c|c|c|c|c|c|}
\hline $\begin{array}{l}\text { Construct \& } \\
\text { Dimensions }\end{array}$ & $\begin{array}{c}\text { Dimensions } \\
\& \\
\text { Items }\end{array}$ & $\begin{array}{l}\text { Item } \\
\text { Factor } \\
\text { Loading }\end{array}$ & $\mathrm{R}^{2}$ & $\begin{array}{c}\text { Composite } \\
\text { Reliability } \\
\text { (CR) (above } \\
0.6 \text { ) }\end{array}$ & $\begin{array}{c}\text { Average } \\
\text { Variance } \\
\text { Extracted (AVE) } \\
\text { (above } 0.5 \text { ) }\end{array}$ \\
\hline \multirow{5}{*}{ Crowdfunding } & Donation & 0.96 & 0.91 & \multirow{5}{*}{0.903} & \multirow{5}{*}{0.653} \\
\hline & Sponsoring & 0.86 & 0.73 & & \\
\hline & Preselling & 0.77 & 0.59 & & \\
\hline & $\begin{array}{l}\text { Social } \\
\text { Lending }\end{array}$ & 0.74 & 0.55 & & \\
\hline & Equity & 0.68 & 0.47 & & \\
\hline \multirow{3}{*}{ Donation } & D1 & 0.72 & 0.52 & \multirow{3}{*}{0.757} & \multirow{3}{*}{0.511} \\
\hline & D2 & 0.65 & 0.42 & & \\
\hline & D3 & 0.77 & 0.59 & & \\
\hline \multirow{3}{*}{ Sponsoring } & S1 & 0.88 & 0.70 & \multirow{3}{*}{0.923} & \multirow{3}{*}{0.800} \\
\hline & $S 2$ & 0.95 & 0.90 & & \\
\hline & S3 & 0.85 & 0.72 & & \\
\hline \multirow{3}{*}{ Preselling } & P1 & 0.69 & 0.47 & \multirow{3}{*}{0.873} & \multirow{3}{*}{0.699} \\
\hline & $\mathrm{P} 2$ & 0.90 & 0.82 & & \\
\hline & P3 & 0.90 & 0.80 & & \\
\hline \multirow{3}{*}{ Social Lending } & SL1 & 0.92 & 0.85 & \multirow{3}{*}{0.896} & \multirow{3}{*}{0.743} \\
\hline & SL2 & 0.72 & 0.52 & & \\
\hline & SL3 & 0.93 & 0.86 & & \\
\hline \multirow{3}{*}{ Equity } & EQ1 & 0.86 & 0.73 & \multirow{3}{*}{0.847} & \multirow{3}{*}{0.650} \\
\hline & EQ2 & 0.71 & 0.50 & & \\
\hline & EQ3 & 0.84 & 0.70 & & \\
\hline \multirow{4}{*}{$\begin{array}{l}\text { Entrepreneur } \\
\text { Self-efficacy }\end{array}$} & ES1 & 0.79 & 0.63 & \multirow{4}{*}{0.822} & \multirow{4}{*}{0.539} \\
\hline & ES2 & 0.72 & 0.53 & & \\
\hline & ES3 & 0.61 & 0.37 & & \\
\hline & ES4 & 0.80 & 0.65 & & \\
\hline
\end{tabular}

The values of factor loading for every item of two constructs that comprise of both crowdfunding and entrepreneur self-efficacy together with the squared multiple correlations or $\mathrm{R}^{2}$, , CR and AVE for every construct as shown in Table 1 which indicated both latent constructs (i.e. Crowdfunding and Entrepreneur Self-efficacy) have achieved Unidimensionality; Convergent Validity, Internal Reliability, and Construct Reliability. Moreover, the Discriminant Validity is assessed through correlation and also through Discriminant Validity Index Summary. According to Awang (2015) one of the criteria for Discriminant Validity is the correlation between exogenous constructs must not exceed 0.85 (Awang et al., 2017a; Hoque et al., 2017b; Hoque and Awang, 2016a; Kline,1998). Table 2 which indicated the Discriminant Validity Index Summary as well as the diagonal value in Table 2 is 
the square-root of AVE for the respective constructs, while other values are the correlation between constructs. The Discriminant Validity of the constructs is achieved when the diagonal values (i.e. the square-root of AVE for the respective constructs) are greater than any values in their rows, and columns respectively (Awang et al., 2017a; Hoque et al., 2017a, Hoque et al., 2017b; Hoque and Awang, 2016a; Awang, 2015; Fornell and Larcker, 1981).

Table 2: Discriminant Validity Index Summary

\begin{tabular}{lcc}
\hline Construct & Crowdfunding & $\begin{array}{c}\text { Entrepreneur } \\
\text { Self-efficacy }\end{array}$ \\
\hline Crowdfunding & $\mathbf{0 . 8 0 8}$ & \\
\hline $\begin{array}{l}\text { Entrepreneur Self- } \\
\text { efficacy }\end{array}$ & 0.710 & $\mathbf{0 . 7 3 4}$ \\
\hline
\end{tabular}

The correlation value between latent construct Crowdfunding and Entrepreneur Self-efficacy is 0.710. As the Square-root of AVE for both constructs (in diagonal) are greater than the value of correlation between the two constructs, the discriminant validity of these two constructs is achieved (Awang et al., 2017a; Hoque et al., 2017a; Hoque et al., 2017b; Kashif et al., 2016; Hoque and Awang, 2016a; Awang et al., 2015; Fornell and Larcker, 1981; Mohamad et al., 2016; Yusof et al., 2017;).

\section{The Structural Model}

As shown in Figure 3 , the hypothesis $H_{1}$ is supported. In $H_{1}$, crowdfunding has a significant and positive effect on entrepreneur self-efficacy of the firms $(\beta=0.924, P=.001)$. The structural model explains $50.3 \%$ variance in entrepreneur self-efficacy.

Table 3: Squared Multiple Correlations $\left(\mathbf{R}^{2}\right)$

\begin{tabular}{lr}
\hline Variable & Estimate $\left(R^{2}\right)$ \\
\hline Entrepreneur Self-efficacy & $\mathbf{0 . 5 0 3}$ \\
\hline
\end{tabular}

The value of $\mathrm{R}^{2}$ in Table 3 indicates that the exogenous construct in the model, namely crowdfunding, manage to estimate $50.3 \%$ of entrepreneur self-efficacy. 
INTERNATIONAL JOURNAL OF ACADEMIC RESEARCH IN BUSINESS AND SOCIAL SCIENCES

Vol. 8, No. 12, Dec, 2018, E-ISSN: 2222-6990@ 2018 HRMARS

Table 4: Standardized Regression Weights of CE on IP

\begin{tabular}{lccr}
\hline Variable & Path & Variable & Estimate \\
\hline $\begin{array}{l}\text { Entrepreneur } \\
\text { Self-efficacy }\end{array}$ & $\leftarrow$ & Crowdfunding & $\mathbf{0 . 7 1 0}$ \\
\hline
\end{tabular}

Table 4 base on Figure 3 showed that the standardized regression (which indicate standardized influence) of crowdfunding on entrepreneur self-efficacy is at 0.71 . This value can be obtained from Figure 3.

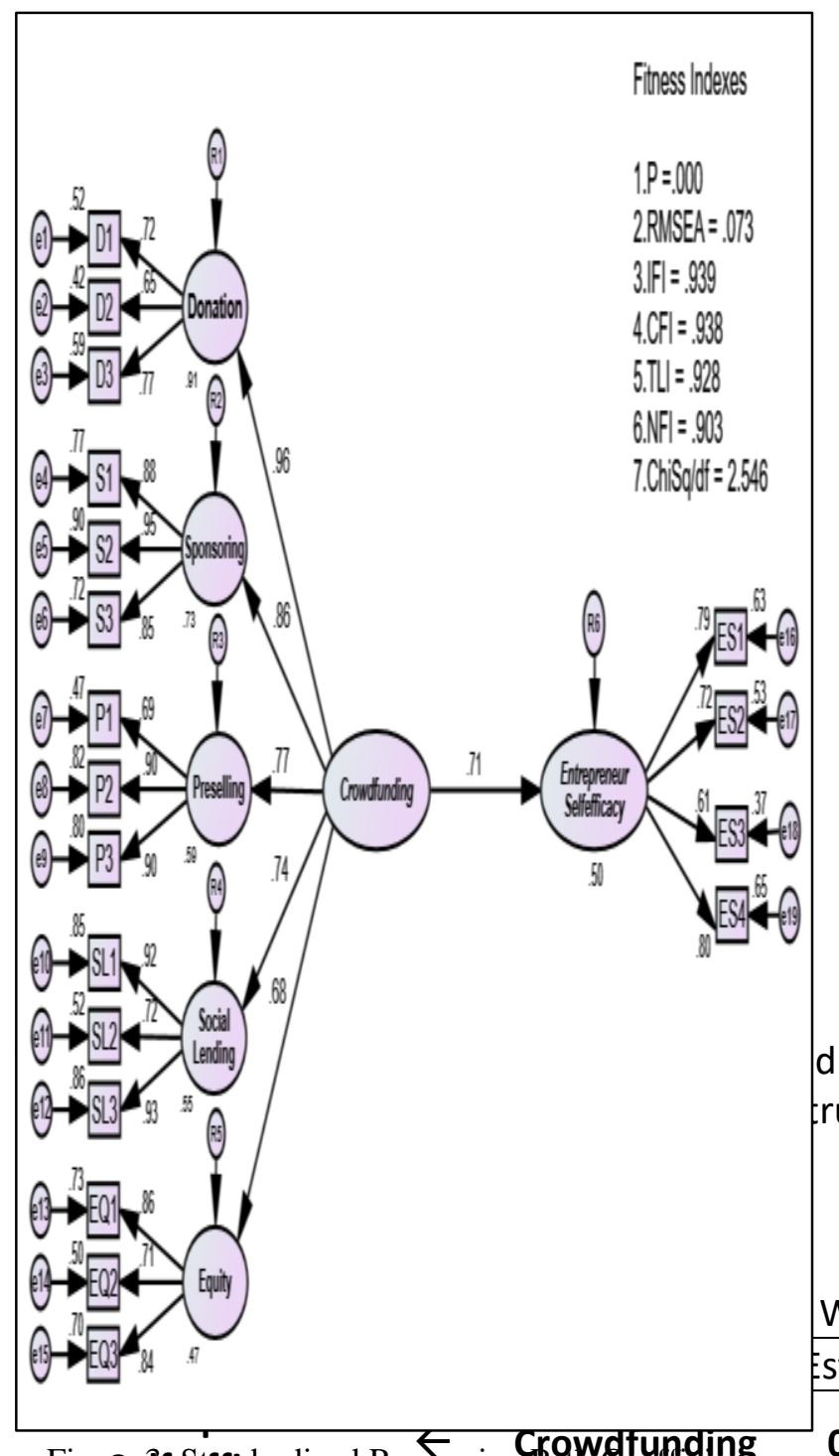

Figuseff-effiearejzed Regression Crowdthonding Note: $* * * \mathrm{P}<0.01$

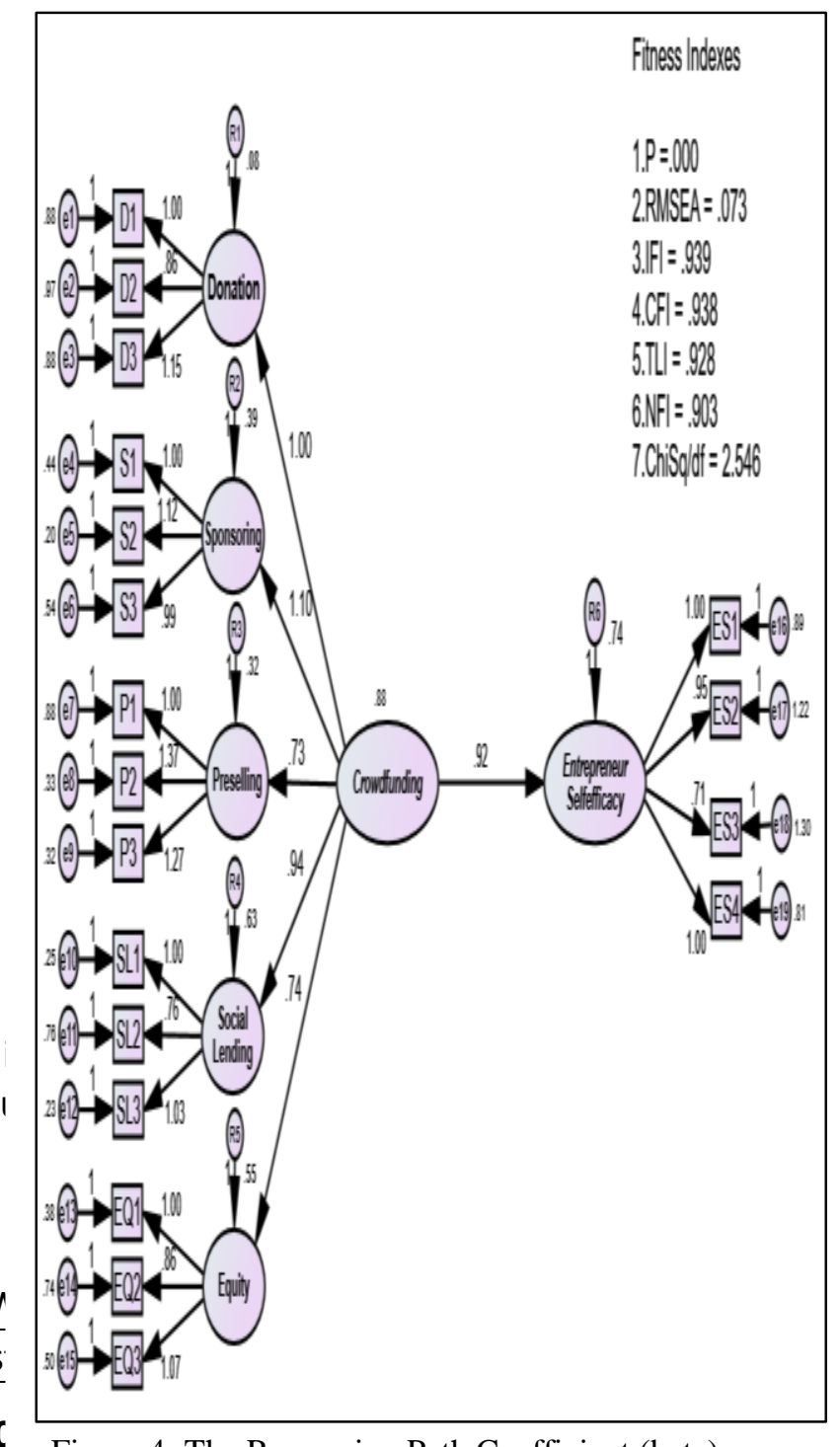

Figure 4: The Regression Path Coefficient (beta) 
The hypothesis of this study was spelt out as: Crowdfunding has a positive and significant effect on Entrepreneur Self-Efficacy of the firms in Bangladesh. The result in Table 5 showed that the level of significance for regression weight indicates that the probability of getting a CR as large as 9.197 in absolute value is 0.001 . In other words, the effect of Crowdfunding on entrepreneur self-efficacy of the firms is highly significant. Consequently, the beta coefficient for the effect of Crowdfunding on entrepreneur self-efficacy was 0.924 , which means that for each unit increase in crowdfunding, the entrepreneur self-efficacy increased by 0.924 . Therefore, the hypothesis was supported. Hence, this research suggested that there is a straightforward requirement and demand for Crowdfunding to increase entrepreneur self-efficacy for their business and to help in the national GDP of Bangladesh.

\section{Conclusion}

In order to prove the need of crowdfunding, we have explained and statistically proved that how crowdfunding can provide an additional channel through which firms can obtain finance and take an advantage of fully exploiting the potential of the internet as well as to create self-efficacy of entrepreneurs. Advantage of crowdfunding against business angels is that while angel investors rely mostly on word-of-mouth, crowdfunding is actually matching up the investors with the best company of their choice. Crowdfunding is not always a better solution for SMEs as for crowdfunding the entrepreneurs have to disclose their business idea and strategy in public specially through internet or in online. Therefore, it might be harmful for firms with unique, innovative ideas that their business model gets duplicated by others. Nevertheless, crowdfunding is crucial for better SME performance through entrepreneur's self-efficacy.

\section{References}

Afthanorhan, A., Awang, Z., \& Fazella, S. (2017). Developing the patients' loyalty model for medical tourism industry: the case of Malaysia. International Journal of Society Systems Science, 9(2), 139-164.

Awang, Z. (2015). SEM made simple: A Gentle Approach to Learning Structural Equation Modeling. Bandar Baru Bangi: MPWS Rich Resources.

Awang, Z.; Afthanorhan, A.; Mohamad, M.; and Asri, M. A. M. (2015). An evaluation of measurement model for medical tourism research: the confirmatory factor analysis approach, International Journal of Tourism Policy, vol. 6, no. 1, pp. 29-45.

Awang, Z., Ahmed, U., Hoque, A. S. M. M., Siddiqui, B. A., Dahri, A. S., and Muda, H. (2017a). The Mediating Role of Meaningful Work in the Relationship Between Career Growth Opportunities and Work Engagement, International Academic Confernce on Business and Economics (IACBE 2017), Faculty of Economics and Management Sciences (FESP), Universiti Sultan Zainal Abidin (UniSZA), October 07-08.

Awang, Z., Hoque, A. S. M. M., Muda, H., and Salleh, F. (2017b). The Effects of Crowdfunding on Entrepreneur's Self-Belief, International Academic Confernce on Business and Economics (IACBE 2017), Faculty of Economics and Management Sciences (FESP), Universiti Sultan Zainal Abidin (UniSZA), October 07-08.

Bandura, A. (1997). Self-efficacy: The exercise of control. W. H. Freeman and Company. 
INTERNATIONAL JOURNAL OF ACADEMIC RESEARCH IN BUSINESS AND SOCIAL SCIENCES

Vol. 8, No. 12, Dec, 2018, E-ISSN: 2222-6990 @ 2018 HRMARS

Bellefl amme, P., and Lambert. T. (2014). Crowdfunding: Some empirical fi ndings and microeconomic underpinnings. Forum Financier: Revue Bancaire et Financière 2014(4): 288-296.

Best, J., and Neiss. S. (2014). Crowdfunding: A historical perspective. In Crowdfunding. A guide to raising capital on the Internet, ed. S. Dresner, 3-14. Hoboken: Wiley.

Bolton, J.E. (1971). Report of the committee of inquiry on small firms. Cmnd. 4811, London: HMSO.

Bottiglia, R., and Pichler, F. (2016). Crowdfunding for SMEs. Springer, Macmillan Publishers Ltd. London.

Chen, C., Greene, P.G., and Crick, A. (1998). Does entrepreneurial self-efficacy distinguish entrepreneurs from managers. Journal of Business Venturing 13, 295-316.

Dapp, T. F. (2013). Crowdfunding. An alternative source of funding with potential, Deutsche Bank Research, Banking and Technology Snapshot, March. www.dbresearch.com

De Buysere, K., Gajda, O., Kleverlaan,R., and Marom, D. (2012). A framework for European crowdfunding. www.crowdfundingframework.eu

Dix, A., and C. Luzar. (2014). Current market dynamics. In Crowdfunding. A guide to raising capital on the Internet, ed. S. Dresner, 47-80. Hoboken: Wiley

Fornell, C., Larcker, D.F. (1981), Structural equation models with unobservable variables and measurement error: Algebra and statistics. Journal of Marketing Research, 18(3), 328-388.

Hagedorn, A., and Pinkwart. A. (2016). The financing process of equity-based crowdfunding: An empirical analysis. In Crowdfunding in Europe. State of the art in theory and practice, eds. D. Brüntje, and O. Gajda, 71-85. Berlin: Springer.

Hair, J.F., Hult, G.T., Ringle, C.M., Sarstedt, M. (2014). A Primer on Partial Least Squares Structural Equation Modelling. Thousand Oaks, California: SAGE Publications, Inc.

Harrison, R. T., and Mason, C. M. (1992). International perspectives on the supply of informal venture capital. Journal of Business Venturing, 7(6), 459-475.

Hemer, J. (2011). A snapshot on crowdfunding. Working papers firms and regions, No. R2/2011.

Hoque, A. S. M. M.; Awang, Z.; Jusoff, K.; Salleh, F.; and Muda, H. (2017a). Social Business Efficiency: Instrument Development and Validation Procedure using Structural Equation Modelling, International Business Management, vol. 11, no. 1, pp. 222-231.

Hoque, A. S. M. M., Awang, Z., and Salam, S. (2017b). The Effects of Relationship Marketing on Firm Performance: Small and Medium Enterprises (SMES) in Bangladesh, 1st International Conference on Business and Management (ICBM-2017), BRAC Business School (BBS), BRAC University, Dhaka, Bangladesh, September 21-22.

Hoque, A. S. M. M. and Awang, Z. (2016a). The Sway of Entrepreneurial Marketing on Firm Performance: Case of Small and Medium Enterprises (SMES) in Bangladesh, Terengganu International Business and Economics Conference (TiBEC-V), Terengganu, Universiti Teknologi Mara (UiTM), pp. 174-194.

Hoque, A. S. M. M. and Awang, Z. (2016b). Exploratory Factor Analysis of Entrepreneurial Marketing: Scale Development and Validation in the SME context of Bangladesh, International Social Sciences and Tourism Research Conference, Terengganu, UniSZA, pp. 20-22.

Kashif, M., Samsi, S. Z. M., Awang, Z., \& Mohamad, M. (2016). EXQ: measurement of healthcare experience quality in Malaysian settings: A contextualist perspective. International Journal of Pharmaceutical and Healthcare Marketing, 10(1), 27-47. 
INTERNATIONAL JOURNAL OF ACADEMIC RESEARCH IN BUSINESS AND SOCIAL SCIENCES

Vol. 8, No. 12, Dec, 2018, E-ISSN: 2222-6990 @ 2018 HRMARS

Kline, R. B. (1998). Principles and practice of structural equation modeling. New York: Guilford.

Macmillan Committee. (1931). Report of the committee on finance and industry. Cmnd. 3897, London: HMSO.

McMullen, J.S. and Shepherd, D.A. (2006). Entrepreneurial action and the role of uncertainty in the theory of the entrepreneur. Academy of Management Review, 31(1), 132-152.

Mohamad, M., Mohammad, M., Mat Ali, N. A., \& Awang, Z. (2016). The impact of life satisfaction on substance abuse: delinquency as a mediator. International Journal of Adolescence and Youth, $1-11$.

Moritz, A., and Block, J. (2016). Crowdfunding: A literature review and research directions. In Crowdfunding in Europe. State of the art in theory and practice, eds. D. Brüntje, and O. Gajda, 25-53. Berlin: Springer.

Nunnally, J. C. (1978). Psychometric Theory (2 ${ }^{\text {nd }}$ ed.). New York: McGraw-Hill.

Pierrakis, Y., and Collins, L. (2013). Crowdfunding: A new innovative model of providing funding to projects and businesses. SSRN Working Paper, May.

Rauch, A. and Frese, M. (2007). Let's put the person back into entrepreneurship research: a metaanalysis on the relationship between business owners' personality traits, business creation, and success. European Journal of Work and Organizational Psychology, 16(4), 353-85.

Shane, S. (2003). A General Theory of Entrepreneurship: The Individual-Opportunity Nexus. Edward Elgar Publishing Limited, Northampton, MA.

Silver, L., Berggren, B., Fili, A. (2016). The role of crowdfunding in entrepreneurial ventures: an analysis of recent trends in Sweden. Investment Management and Financial Innovations, 13(1), 221-229. https://doi.org/10.21511/imfi.13(1-1).2016.09

Ward, C. and Ramachandran, V. (2010). Crowdfunding the next hit: Micro-funding online experience goods. Proc. of NIPS, Workshop on Computational Social Science and the Wisdom of Crowds.

Wardrop, R., Zhang, B., Rau, R., and Gray, M. (2015). Moving mainstream. The European alternative finance benchmarking report. Cambridge Centre for Alternative Finance and Ernst \& Young, February. www.jbs.cam.ac.uk

Wilson, F., Kickul, J., and Marlino, D. (2007). Gender, entrepreneurial self-efficacy, and entrepreneurial career intentions: Implications for entrepreneurship education. Entrepreneurship Theory and Practice, 13, 387-406.

Wilson, K. E., and Testoni, M. (2014). Improving the role of equity crowdfunding in Europe's capital markets. Bruegel Policy Contribution Issue 2014/09, August.

Wingerden, R. V., and Ryan, J. (2011). Fight for Funds: An Exploratory Study into the Field of Crowdfunding. School of Economics and Management, Lund University.

Yusof, Y., Awang, Z., Jusoff, K., \& Ibrahim, Y. (2017). The influence of green practices by non-green hotels on customer satisfaction and loyalty in hotel and tourism industry. International Journal of Green Economics, 11(1), 1-14. 